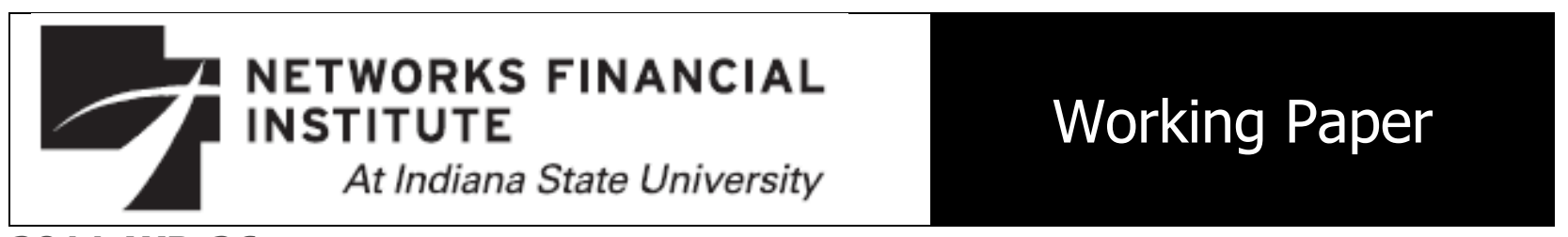

2011-WP-26

November 2011

\title{
Inflation and Asset Prices
}

John A. Tatom

Abstract: Changes in the general level of prices and inflation have profound effects on asset prices. There are several reasons for these effects and the influence differs depending on the source of the inflation and whether it is expected or not. To understand these effects, it is important to clarify what is meant by inflation, the pure theory of the sources of inflation, how inflation affects goods and services prices and how it affects the assets that are used to finance production, both equity prices and fixed income assets. This article reviews the theory of inflation, its sources and effects on asset prices, especially equity, bond and real asset prices. The simplest and broadest economic model suggests that money is a veil and that changes in its value, the price level, and its rate of depreciation, inflation, have no real effects on the economy, especially asset prices and real rates of return on assets. There are a variety of reasons to expect that inflation is not "neutral," however. This article focuses on several factors that give rise to real adverse effects of inflation on asset prices, including supply shocks that reduce wealth and raise prices, and tax effects of inflation that arise from a lack of full indexation of the tax system. Inflation has had large effects on asset prices in the United States, especially during the Great Inflation from 1965 to 1984. The evidence here supports these sources of real effects of inflation.

About the Author: John A. Tatom is Associate Professor of Finance and Director of Research at Networks Financial Institute at Indiana State University. He has published widely on international and domestic monetary and fiscal policy issues, the macroeconomics of supply, especially oil and energy price shocks, exchange rates, and on financial innovations.

Keywords: Inflation, asset prices, supply shocks, real rate of interest, real rate of return on equity.

\section{JEL Classifications: G0, E31, E44.}

The views expressed are those of the individual author and do not necessarily reflect official positions of Networks Financial Institute. Please address questions regarding content to John A. Tatom at john.tatom@indstate.edu. Any errors or omissions are the responsibility of the author. NFI working papers and other publications are available on NFI's website (www.networksfinancialinstitute.org). Click "Thought Leadership" and then "Publications/Papers." 


\section{Inflation and Asset Prices}

Changes in the general level of prices and inflation have profound effects on asset prices. There are several reasons for these effects and the influence differs depending on the source of the inflation and whether it is expected or not. To understand these effects, it is important to clarify what is meant by inflation, the pure theory of the sources of inflation, how inflation affects goods and services prices and how it affects the assets that are used to finance production, both equity prices and fixed income assets.

Inflation has had large effects on asset prices in the United States, especially during the Great Inflation from 1965 to 1984 . There have been lesser bouts of inflation since then and an acceptable and stable pace of inflation has been elusive for more than a few years at a time. The Great Inflation was followed by the Great Moderation, a reduced volatility of real gross domestic product (GDP) growth, which some analysts argue was caused by improvements in monetary policy in pursuing lower and more stable inflation; see Bernanke (2004). Olivier Blanchard and John Simon (2001), for example, have documented that the variability of quarterly growth in real output (as measured by its standard deviation) has declined by half since the mid-1980s, while the variability of quarterly inflation has declined by about two thirds. Kim and Nelson (1999) and McConnell and Perez-Quiros (2000) were among the first to note the reduction in the volatility of output. Kim, Nelson, and Piger (2004) show that the reduction in the volatility of output is quite broad based, affecting many sectors and aspects of the economy. Using more formal econometric methods, Kim, Nelson, and Piger (2004) also found that structural breaks in the volatility and persistence of inflation occurred about the same times as the changes in output volatility. This chapter does not explore what constitutes an acceptable rate of inflation.

The Federal Open Market Committee of the Federal Reserve System (Fed) has struggled with this question and the related question of inflation targeting for many years. The policy and investment communities have consensus estimates that the Fed aims for a two percent annual rate of inflation maintained on a year-over-year basis, but it tolerates moves above and below this, especially when the deviation of inflation is perceived by the Fed and the market to be temporary. The European Central Bank targets more explicitly on inflation, aiming for a zero to two percent inflation rate, closer to the top of the range, again on a year over year basis. The reasons for tolerating a positive target rate of inflation appear to be twofold. First, economists expect there to be some bias in prices and inflation due to technological change that results in measured inflation that actually reflects quality improvements. Second, there is reluctance on the part of policymakers to experience deflation, a falling general level of prices. Given the random variation of inflation measures, targeting zero inflation could result in frequent and sometimes persistent experiences of negative measures of inflation. This article reviews the 
theory of inflation, its sources and effects on asset prices, especially equity, bond and real asset prices. The theory behind these effects is kept to the essentials and is reduced to its simplest detail.

Inflation is explored in section 1, including what it is and what it is not. The important distinction between a price level and relative prices change, the difference between a sustained pace of price level change and a one-time or transitory change, and the link between inflation and monetary policy are developed, as well as the implications for asset prices. This section also discusses the variety of price index and inflation measures and the usefulness of "core" measures of inflation. Section II looks at the role of money in the economy and the notion of money as a veil, hiding the fundamental real activity in an economy, and establishing the theoretical benchmark of an economy where money is neutral so that inflation has no real effects on activity and in particular on real asset prices and returns. In section III, the key hypotheses of how inflation affects asset prices by altering real interest rates or the required real rate of return on equity, and/or by affecting real earning on corporate equity, are examined and evidence is provided supporting both, especially the equity effects. Section IV concludes.

\section{What is Inflation?}

Economists and financial analysts recognize several key distinctions in discussing inflation. The most important is that the term refers to the sustained rate of depreciation of the purchasing power of a unit of local currency over time. A rise in the price of a kilo of beef from $\$ 10$ per kilo to $\$ 11$ per kilo reflects the fact that a unit of money buys less than it did before: after the price rise, $\$ 10$ buys only 0.91 pounds of meat instead of one pound. If only the beef price rises, then this is referred to as a relative price change; beef has become more expensive relative to everything else, including money. A rise in the relative price of one good or another is not inflation. Beef has become more expensive relative to everything else. If all prices move in line with beef prices, however, then the price of a market basket of goods and services rises 10 percent, or the value of money falls by roughly 10 percent (9.1 percent). Measured on a continuously compounded rate basis (differences in the natural logarithms), prices rose 9.53 percent and the value of money relative to goods and services fell by exactly the same extent (9.53 percent). If the general level of prices, beef and other goods and services, rose for some special reason that is not expected to continue, this is referred to as a rise in the price level, or sometimes as "temporary inflation," but not inflation. 


\section{I.1 Inflation is a Monetary Phenomenon}

Milton Friedman famously coined the expression that "inflation is always and everywhere a monetary phenomenon." This captures the fact that the principal cause of inflation is the excess of growth in the money stock relative to that of money demand. Like other goods or services, an increase in the price of money (relative to goods and services) depends on its relative scarcity, so growth in supply relative to demand causes decreases in the value of money or inflation. With fiat money under the control of central banks, the supply of money is determined by actions of the central bank and by changes in preferences for currency or deposits of the public and depository institutions, or by shifts in preferences for broader deposits at depository institutions in the case of broader measures of monetary aggregates. Since the central bank can readily detect shifts in these preferences and offset their influence on monetary aggregate measures, changes in the stock of money are fully under the control of the central bank. The demand for money depends on the cost of holding money and its usefulness in facilitating transactions or providing liquidity in asset portfolios. The cost of holding a given amount of money is the short term nominal interest rate, typically measured by the most liquid safe domestic security like the U.S. Treasury bill rate in the United States. This captures the alternative return from holding a very liquid and safe asset instead of currency or a bank deposit that can be used for third party payment or readily and cheaply converted into such a transaction deposit. Alternatively, the nominal interest rate reflects the real interest rate foregone by holding money and the rate of depreciation expected on holding money, i.e. the expected rate of inflation. The transaction demand for money depends on income or real GDP, and measures such as the size of wealth relative to income, alternative rates of return on alternative assets and the liquidity of wealth and the degree of uncertainty can influence the demand for money. See Friedman (1956) for the classic statement of the demand for money and its link to inflation.

\section{I.2 Non-Monetary Factors}

There are other factors that can account for temporary inflation or price level increases. In particular, as described above, the general level of prices can be raised by a decline in money demand. A principal source of such a decline is a negative shock to aggregate supply. This can occur because of a reduction in resources available or a reduction in total factor productivity. Rasche and Tatom (1977) develop the aggregate supply theory that explains the loss in natural output and price level rise associated with a shock to the relative price of energy. Rasche and Tatom (1981) develop the theory of supply shocks more fully in a broader study of energy or other supply shocks. Examples of the former are plagues, wars, strikes or a decline in resource use because of shock to the relative price of a key resource such as an oil price shock. An example of the latter is a crop failure or another natural disaster that significantly reduces 
output, given resource usage. Supply shocks can be permanent or transitory. When permanent, they can lead to a permanent rise in the price level, experienced as temporary inflation. The most important empirical example of this is a rise in the relative price of oil that raises the relative price of energy. When transitory, the relative price of the affected good or service rises temporarily and then returns to its original level after the source of the shock is removed. The price level reflects the same transitory rise and fall in this case. The best empirical example of this is a crop failure, drought or natural disaster that temporarily reduces output in a key sector of the economy. Conceptually, a permanent continuing shock to supply could be a source of a sustained rise in the relative price of a resource and therefore inflation, but that requires an ongoing reduction in the employment of some resource that reflects or causes the reduction in economic growth.

\section{I.3 Measures of Inflation}

There are several measures of inflation. The broadest measures are the chain weight GDP deflator, which measures changes in the price index for the bundle of final goods and services that make up the nation's output, or real GDP. Since consumer expenditures make up the largest share of GDP and are the prices most relevant to consumers, analysts often focus on the chain weight personal consumption expenditure (PCE) deflator as the benchmark for assessing inflation. Many analysts focus on the consumer price index (CPI) as the relevant measure of inflation. This measure has a history of problems. Most importantly, the housing component of the index was revised in the 1990s to better measure the price of housing, but the earlier series was not revised in the same way, making the index less reliable for longer term studies. Figure 1 shows the year-over-year measure of the rate of increase in the PCE deflator, a socalled "core" inflation measure, and the CPI. All three measures are broadly similar, though the CPI-based measure is slightly higher and more volatile. The Great Inflation in 1965-84 stands out, but there are other episodes of relatively high measured inflation.

Since there are some prices that are very volatile but do not reflect the underlying trend in the value of money or of the general level of prices, statisticians and analysts often distinguish a "core" measure of inflation from the overall measure. The measurement of core inflation uses price indexes that remove the price movements in non-core items, most often the prices of food and energy, but sometimes other items such as housing rent or other volatile prices. The reasons for excluding items from an inflation measure are that the volatile changes are not expected to persist and indeed, at least in the case of food prices, they are expected to cancel out over time. In any case, the sustained rate of price change, inflation, is expected to be obscured by the overall measure of inflation measured by the broader index of the general level of prices. This may not be correct, however, so care must be exercised in the choice of inflation measure. Crone, Khettry, Mester and Novak (2006) provide evidence that overall PCE 
deflator inflation is a better predictor of its future rate than is a core measure. Kiley (2008) reaches the opposite conclusion about how to estimate the underlying trend of inflation. Mankiw, Reis and Wolfers (2003) provide an earlier survey on the issues involved in developing inflationary expectations; they suggest that expectations reflect partial and incomplete updating in response to news.

Figure 1

Inflation Measures Surged from the Mid-1960s to 1981, then Slowed

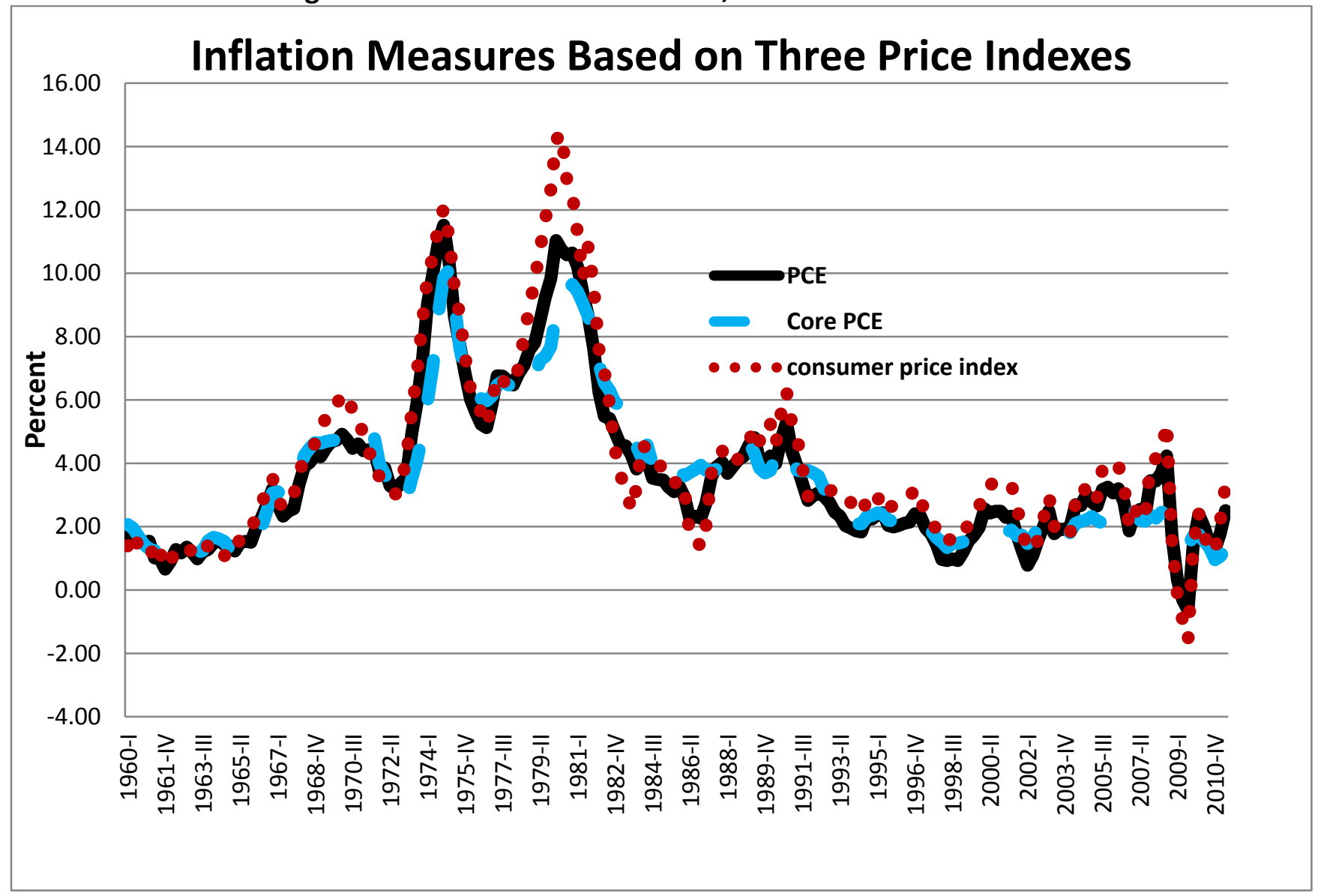

Source: FRED2, Federal Reserve Bank of St. Louis.

In Figure 1, temporary surges in inflation in 1974-75, 1979-81, 1991, 2000 and 2008-09, reflect sharp increases in the relative price of energy. The end of the Iran-Iraq war in 1986 and IraqKuwait war in 2001, led to declines in the relative price of oil and energy that were reflected in declines in prices, or to temporary drops in inflation.

A third critical distinction is that inflation can be expected or unexpected. A surprise in inflation will have different effects on asset prices and economic performance than a rise in expected inflation. Most surprises in inflation arise from shifts in relative prices, especially food or energy prices, and are temporary. More fundamental determinants of inflation evolve more 
predictably and hence the underlying inflation is also more predictable or expected. The key factor differentiating expected and unexpected inflation, in terms of the effects on asset prices is that capital markets incorporate expected inflation in asset demand and supply and in pricing of assets, while unexpected is not incorporated in the same way. The key effects of unexpected inflation arise from redistributions of income and wealth. For example, an unexpected and temporary rise in inflation will redistribute income from creditors, who face an unexpected fall in the purchasing power of their interest income and principal repayments, that is, a fall in their realized real rate of return, while debtors enjoy their corresponding unexpected gain. For owners of firms, there are at least two effects of unexpected inflation. The first is the redistribution of income from creditors to debtors above. Firms that have external debt will benefit from a rise in unanticipated inflation. Their owners, stockholders, will realize the unexpected decline in their real interest payments to their creditors as a gain in real profits. The discounted value of the gain will accrue to stockholders as an unanticipated capital gain in the stock price.

Anticipated inflation usually is not expected to create redistributions of income or wealth. Market participants require compensation for expected changes in the purchasing power of expected future payments in order to acquire assets, and sellers of assets have the wherewithal and willingness to provide such compensation, at least in a simple world where institutions or regulations do not prevent such compensation. More broadly, it is anticipated inflation that has more sweeping effects on asset and other prices and that affects portfolio allocation, output and economic growth.

II. Money is a Veil?

The simplest model of inflation and asset prices assumes that there are no frictions in markets, there are no transaction or adjustment costs and that information is freely available. In this model, a rise in expected inflation raises nominal demand prices for unchanged quantities of goods and services along new and higher expected inflation paths. It simultaneously raises prices of resources and marginal costs by equal percentages, at given quantities of goods and services and resource input flows. Prices freely move up at the specified rates over time, with no distortion of resource employment or output. Relative prices of resources, goods and services and assets are unaffected, as are real rates of return on assets. Since future real cash flows are unaffected, real rates of return to capital are not affected either. Equity prices rise in line with the higher expected inflation rate.

Existing nominal fixed income products are affected, however, when the expected rate of inflation increases. This occurs because the rate of depreciation in the purchasing power of future nominal cash flows has increased. Following the Fisher equation, named after Irving Fisher, the nominal interest rate on fixed income securities will rise in line with the expected 
rate of inflation to keep the real rate unchanged. In the market for new fixed income securities at each maturity, the nominal interest rate offered for any amount of credit will rise to reflect the higher nominal return from investment products, just as the nominal interest rate from any flow of credit offered will rise to fully reflect an unchanged real interest rate and compensation for the higher expected inflation rate. Thus nominal interest rates will rise by exactly the higher expected rate of inflation, and real interest rates and supplies and demands for credit will be unchanged. The market for existing assets competes with that for existing assets, so that the real rate of return earned over any future period to maturity will be the same in both markets, as will the nominal interest rates. Thus existing contracts for streams of fixed cash returns will reflect a fall in the nominal price of fixed income assets, promising fixed local currency returns.

Figure 2 shows the year-over-year, PCE-based inflation measure along with the 10-year Treasury yield. The Fisher effect indicates that anticipated inflation is priced in to the observed or nominal interest rate.

Figure 2

Inflation Raises Interest Rates

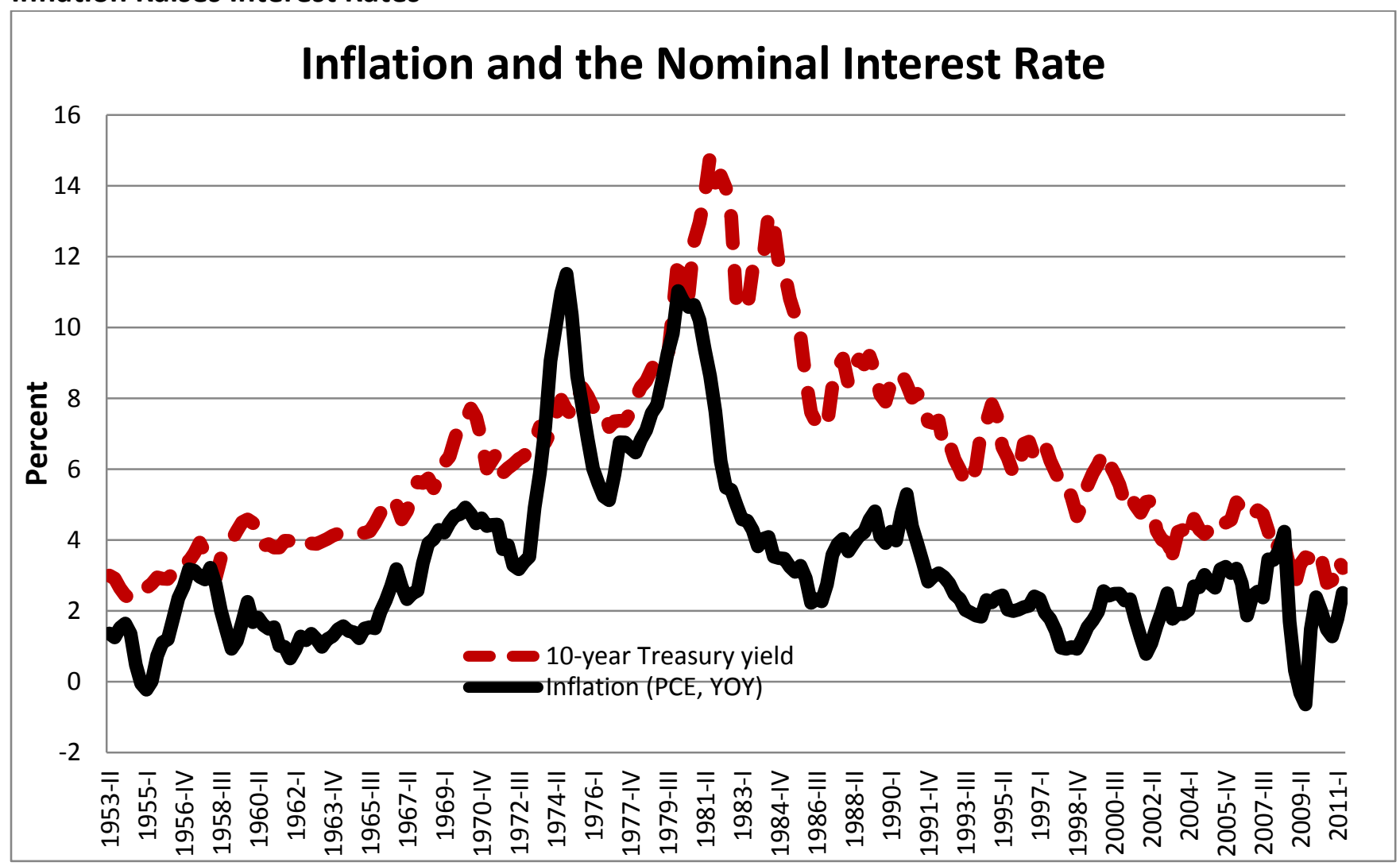

Source: FRED2, Federal Reserve Bank of St. Louis

The decline in the nominal (and real) value of fixed income assets will be greater, the greater the duration of the asset. The effect of a rise in expected inflation on bond prices is rather like 
that of a rise in unexpected inflation, because the rise was unexpected before it changed. But in this simple example, there is no unexpected inflation, only an unexpected changes in the expected inflation rate. Borrowers and lenders both hold a lower real value of debt or credit, respectively, because the future values of nominal debt are smaller than they originally expected. Borrowers and lenders wishing to have a given real value of debt and credit at any point in the future will have to borrow and lend more in nominal terms to keep the real values of debt unchanged.

In this simple model, another key nominal price is the foreign exchange rate. The benchmark for foreign exchange in the simple world is determined by relative purchasing power parity, so that the value of a currency will fall over time relative to another currency, in line with the higher domestic expected rate of inflation compared with unchanged expected inflation abroad. The rate of depreciation in a local currency will equal the expected inflation rate in the economy less the expected inflation rate in the country of origin of the other currency. So long as this holds, the local currency prices of domestic and foreign goods or services will rise at the new expected rate of domestic inflation and the same will be true abroad.

Even in this simple world, currencies will not adjust fully and immediately to a change in the expected inflation rate. In fact, currencies typically overshoot in response to factors booting inflation expectations, falling more than the theory predicts based only on expected future inflation. Some asset prices also adjust more in the short run than higher inflation might suggest. The elasticity of supply of some commodities, for example, is quite inelastic so that increases in nominal demand lead to relatively higher relative prices. These relatively large short-run price adjustments can make commodities an attractive investment option in the short run. Balanced against this argument, however, is that these adjustments are short term.Many commodities are also very sensitive to the business cycle and relatively more cyclical industrial demand, which is quite adversely affected by any subsequent policy tightening in the face of the rise in inflationary expectations.

Where money is a veil and is neutral in having no real effects on resource allocation or incentives to accumulate resources, inflation has purely nominal effects on asset prices. A rise in expected inflation will cause bond prices to fall, as nominal interest rates rise to incorporate the Fisher effect of inflation on nominal interest rates. The fall in bond prices is larger, the longer the duration of the asset, because longer duration cash flows lose more purchasing power due to a given pace of inflation. The real interest rate on bonds is unaffected if money growth is neutral. Real earnings from capital would also be unaffected if all other real factor prices were unaffected by the inflation process. Thus equity prices would rise in line with inflation and equities would be a perfect inflation hedge. 


\section{II.1 Inflation Has Real Effects on Stock Prices}

The most widely accepted hypothesis of a negative effect of inflation on stock prices is that supply shocks that reduce output and raise prices also reduce the marginal productivity of capital, reducing the real future earnings of capital and lowering the value of capital assets and the firm. Bakshi and Chen (1996) point out that a negative correlation between inflation and stock prices has become one of the most commonly accepted empirical facts motivating large numbers of financial and monetary economics studies. They do not cite any studies that include a model in which in which inflation has real effects arising from nominal taxation rules, the focus in the next section. The negative relation of inflation and stock prices occurs instead because of pro-cyclical movements in real interest rates and in inflation, but the empirical support is weak. Fama (1981) and Stulz (1986) argue that a rise in expected inflation reduces wealth and that this in turn lowers the expected return on equities and lowers stock prices. Brandt and Wang (2003) provide an alternative explanation of the negative relationship of stock prices and unexpected inflation. They argue that unexpected inflation affects investor risk preferences, in particular, raising risk aversion and that, in turn, lowers stock prices.

Hess and Lee (1999) argue that the negative correlation of stock prices and inflation depends on the nature of the shocks creating inflation. Their theoretical structure also does not allow inflation to have long-run real effects on output (and, therefore, stock prices). In their view, only adverse supply shocks reduce output and stock prices, causing a temporary surge in inflation. Both their model and evidence apply to unanticipated supply and demand changes. Fama (1981) also attributes the negative relationship to supply shocks. Some studies indicate that inflation reduces economic growth, which should slow the expected growth rate of earnings and lower stock prices; see, for example, Barro (1996). Tatom (2002) shows that both energy price shocks and demand induced inflation have essentially the same effects on stock prices and that stock prices anticipate the expected change in inflation from either. In each case, a rise in inflation raises the Standard \& Poor's (S\&P) earnings-price yield by 1.46 percent. Tatom (2002) also finds that the causality from positive monetary policy shocks to the real federal funds rate to increases in stock prices.

Figure 3 provides a perspective on the negative effect of inflation on equity prices. It shows the real S\&P 500 index, deflated by the PCE deflator, and the PCE-based inflation rate for the period $\mathrm{l} / 1957$ to $\mathrm{Il} / 2011$.

The negative correlation is most apparent during the Great Inflation, 1965-84, when the real stock was depressed. Other periods of relatively higher inflation are also associated with relatively low real stock prices, including the late-1950s and 2007-09. The decline in inflation in 1991-98 was notably associated with a sharp rise in the real stock price. The correlation between the two series is -0.44 , strongly negative. 
Figure 3

Inflation Depresses Real Stock Prices

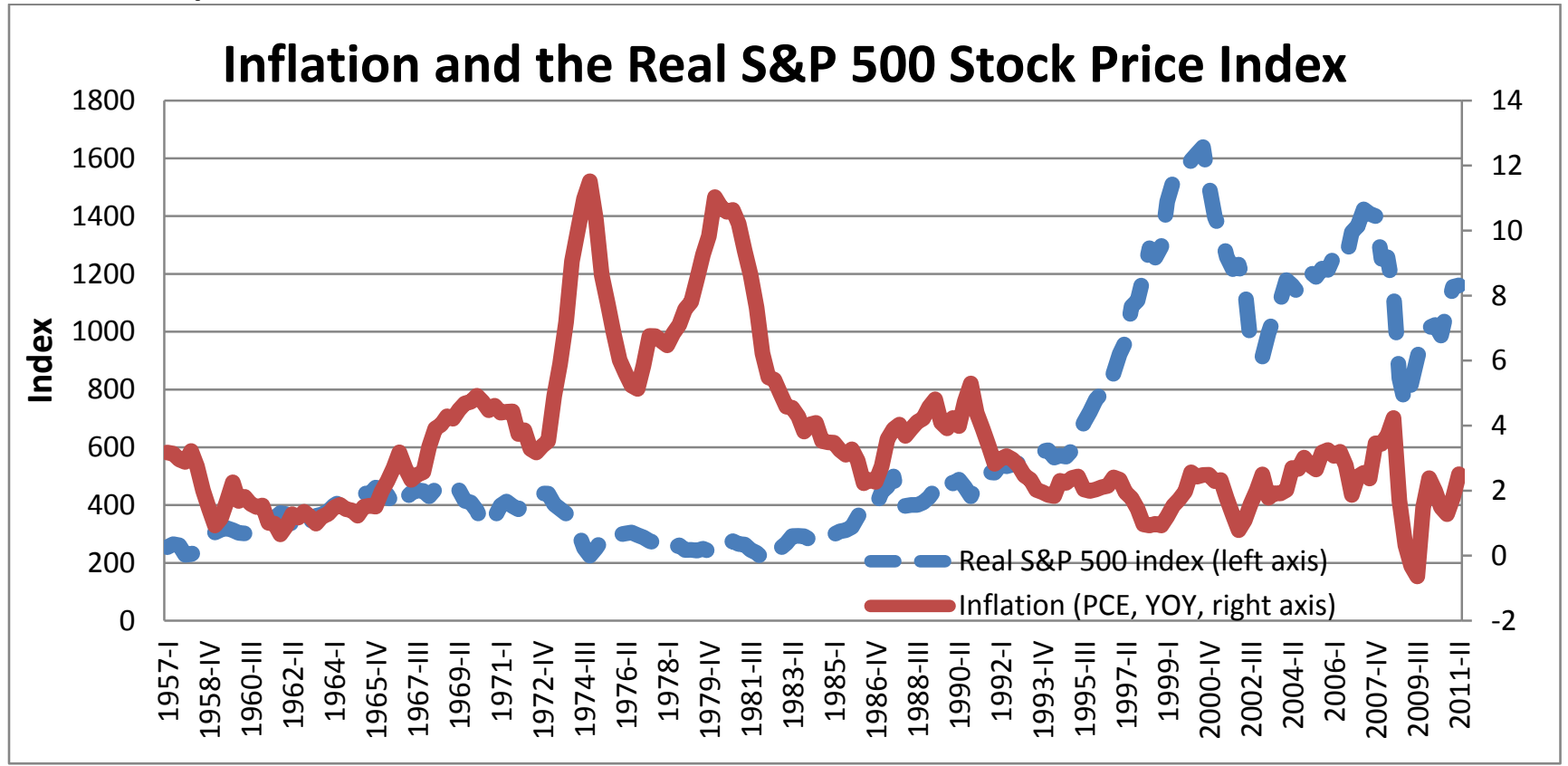

Source: FRED2, Federal Reserve Bank of St. Louis and Standard \& Poor's

III. The Effects of Taxation of Nominal and Real Income

There are theoretical considerations that argue against neutral effects of inflation on asset prices. Moreover, the evidence is more consistent with these theories. There are two taxrelated arguments that indicate that bond and equity prices are reduced because of an increase in expected inflation. Income taxation systems tax nominal incomes. If the tax system is not indexed to adjust nominal incomes measures for inflation, taxes are levied on inflationary changes in income so that real incomes are taxed as well. In that event real asset prices will be depressed by a rise in expected inflation.

\section{III.1 Tax Rate Effects on the Real Rate of Interest}

The first real effect arises through a rise in the real rate of interest. The Fisher equation indicates that the nominal interest rate equals the real interest rate plus the expected rate of inflation. According to the discussion above, a rise in the expected rate of inflation $\left(\pi^{\mathrm{e}}\right)$ will raise the nominal interest rate (i) by an equal amount, leaving the real interest rate ( $r$ ) unaffected. When nominal interest income is taxed, the after-tax interest rate $\left(i_{A T}\right)$ is:

(1) $i_{A T}=(1-t) i$

and the real interest rate is 
(2) $r=\left(r_{A T}+\pi^{e}\right) /(1-t)-\pi^{e}=r_{A T} /(1-t)+t \pi^{e} /(1-t)$

A one-percentage point rise in expected inflation will raise the real interest rate at which bonds and equities are discounted by $t /(1-t)$, which is positive and can be quite large. For example, for a marginal tax rate of one-third, each percentage point of expected inflation raises the real interest rate by 50 basis points and raises the nominal interest rate by 150 basis points. With such a rise in the real cost of funds, producers will reduce investment in real assets, perhaps putting some downward pressure on the aftertax real return on investment. When the real rate of discount rises, bond prices will fall further than otherwise and equity prices will not keep pace with inflation as real equity prices fall. The empirical evidence is at odds with this result. In Figure 2 movements in the inflation rate are not exceeded or even matched by movements in the interest rate. This suggests that the real interest rate falls when inflation rises and falls when it declines, instead of the reverse effect due to a tax effect of inflation on interest rates. In a traditional IS-LM model, ignoring taxes, there is another factor that affects the shortrun adjustment of the real interest rate to a change in expected inflation, ignoring taxes. A rise in the expected inflation rate will raise the expected cost of holding money, given the real interest rate. This will reduce the demand for money as investors shift to bonds or equities, leading to a reduction in the real interest rate and an expansion of aggregate demand, real output and prices. The interest rate effect here is temporary and comparable to a liquidity effect of a monetary expansion. There is little evidence for the United States that there is a liquidity effect, however. The rise in prices has been referred to as the "Friedman surge" in prices, an overshooting of the price level that will eventually go away in the long-run. The simple evidence in Figure 2 is consistent with this effect dominating the tax effect above.

\section{III.2 Tax Effects on Real Earnings}

If one replaces the return to equity in equations (1) - (2), the same analysis applies for equity returns. The evidence of a negative correlation between equity prices and inflation is consistent with such a tax effect, though the evidence for real yields on bonds is not.

There is a second tax effect of inflation on equity prices that is more likely to dominate equity valuation and that reinforces the tax effect on equity prices above. Nominal income taxation does not adjust depreciation allowances or inventory valuation for inflation. Thus, inflation related increases in inventory value are treated as income and taxed, even though there has been no real gain. Similarly, depreciation allowances do not adjust for the higher replacement cost of depreciating assets, so that depreciation cost of capital is understated by an increasing amount over time in an inflationary environment. The higher is the inflation rate and the longer lived an asset is, the greater the understatement of cost, overstatement of taxable income and tax. Thus, real after-tax income from capital assets is depressed when inflation rises. 
Feldstein (1981) and Tatom and Turley (1976) are examples of models in which inflation raises the real tax burden (due principally to nominal accounting of and depreciation expenses) and lowers real after tax earnings and rates of return to capital. Fama and French (1989) provide an explanation of how monetary policy affects stock returns by affecting economic performance, but it is not dependent on tax effects or supply shocks. Nominal income taxation and accounting rules base inventory valuation and asset depreciation rules on fixed nominal prices. Inflation raises the replacement cost of inventory and assets, but accounting values do not reflect this. As a result, when all other costs and revenue keep pace with inflation, accounting depreciation and inventory costs do not, so costs are understated, measured income and taxes are overstated. As a result, true economic income is depressed, as are stock prices that are the present discounted value of after-tax economic income, even if the real cost of capital used to discount future real incomes is unchanged. Interestingly, indirect support for the hypothesis can be found in Piazzesi and Schneider (2008) who show that the Great Inflation led to a portfolio shift by making housing more attractive than equity. This may reflect that depreciation rules for taxation affect corporate income, but not the market value for owner-occupied housing.

Evidence for this hypothesis can be found by examining real after-tax corporate profit and real after-tax economic profit, or profit adjusted for capital consumption and inventory valuation adjustments. The latter measure is the Bureau of Economic Analysis (BEA) of the U.S. Department of Commerce measure of economic profit and is referred to as such here.

Figure 4 shows the BEA measures of after-tax corporate profits and after-tax corporate profits including capital consumption and inventory valuation adjustments, both as a percent of national income.

During the period of the Great Inflation, measured profits exceeded economic profit by relatively large amounts. Measured profit was also relatively high compared with economic profit in 1947-51, when inflation was also relatively high and depreciation rules was more punitive to longer-term assets. The 1981 Tax Act was aimed at reducing the excessive depreciation on capital assets, especially long-term assets such as structures, which were most heavily affected by inflation. Note that after 1981, economic profit fell relative to measured profit. 
Figure 4

Measured Profit Exceeds Economic Profit When Inflation Is Relatively High

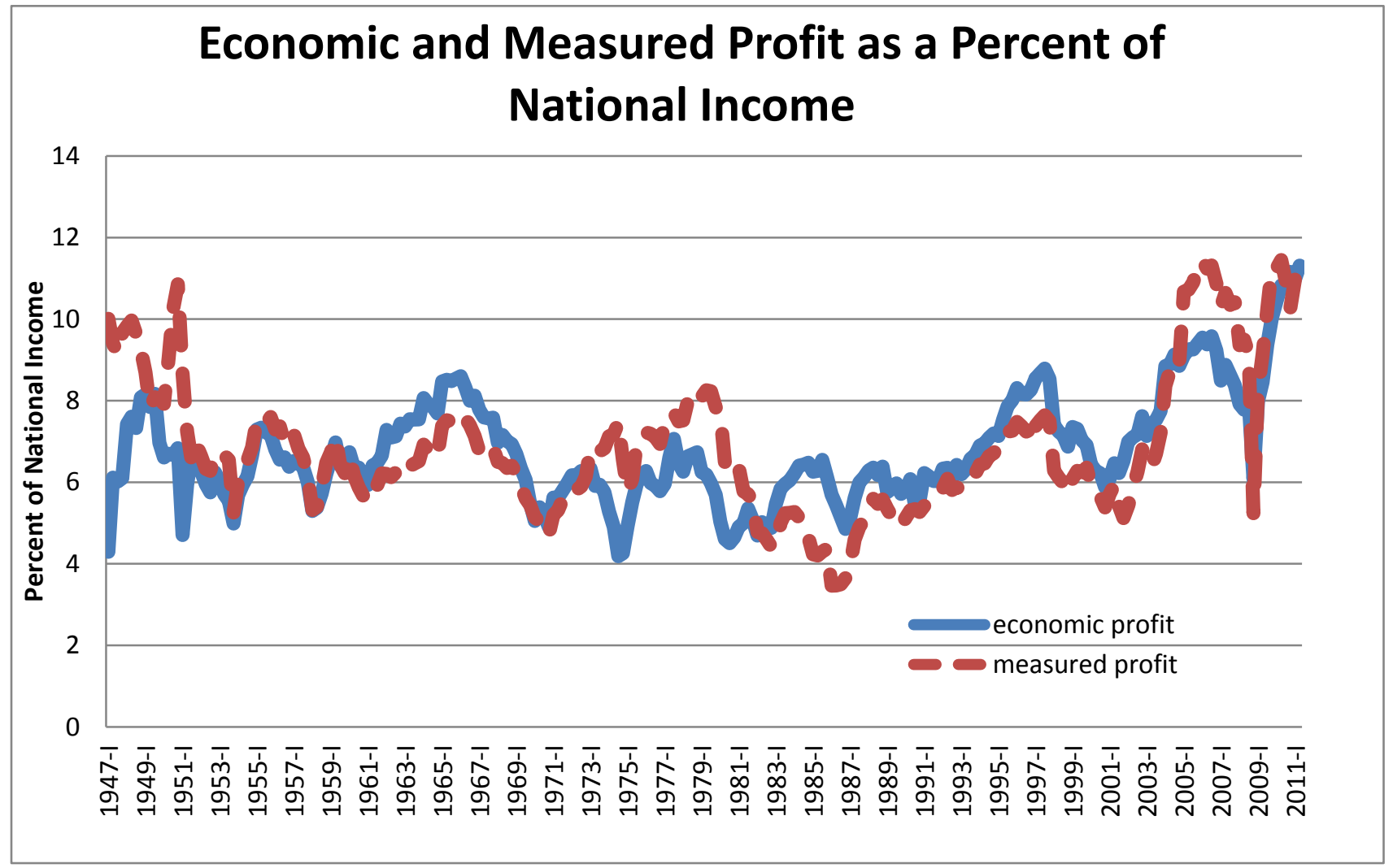

Source: FRED2, Federal Reserve Bank of St. Louis

A simple test of the effect of inflation on economic profit relative to measured profit is to regress inflation $(\pi)$ on the logarithm of the ratio of economic profit to measured profit (ladjp). Other factors influence this ratio, especially the business cycle. Using the log of the capacity utilization rate in manufacturing to capture the influence of the business cycle (LCU), the ratio of economic profit to measured profit over the period II/1972 to II/2011 is (t-statistics in parentheses):

3) $\operatorname{Ladjp}=0.651-0.018 d(\pi)-0.074 \mathrm{~d}($ Icu $)-0.149 \mathrm{Icu}(-1)+0.970$ Ladjp(-1)

(2.23) $(-7.11) \quad(-3.20)$

$(-2.23)$

(43.97)
Adjusted $R^{2}=0.93$
S.E. $=0.051$
D.W. $=2.07$

The standard error (S.E.) of the estimate and the Durbin-Watson Statistic (D.W.) are satisfactory. A one percentage point rise in inflation reduces economic profit relative to measured profit by 1.8 percentage points. A cyclical rise in the capacity utilization rate reduces economic profit as well, somewhat surprising as it implies that measured profit rises relative to economic profit. The inflation result supports the hypothesis that inflation reduced economic 
profit relative to measured profit. But this does not reveal the overall effect on profits by either measure.

To pin down the effects on each measure, the logarithm of real after-tax measure economic profit (Lrecp) and real measured profit (Irp), using the PCE deflator, are estimated to be functions of inflation and the business cycle (lcu). Searches for significant lags from zero to four were conducted and only the estimates with statistically significant determinants are reported. For the period II/1972 to II/2011, the result for real after-tax economic profit is:

4) $d($ Irecp $)=0.011-0.007 d(\pi(-1))+0.796 D($ lcu $)$

Adjusted $\mathrm{R}^{2}=0.07 \quad$ S.E. $=0.062 \quad$ D.W. $=1.88$

While the adjusted $\mathrm{R}^{2}$ is quite low, the independent variables are significant as a group and individually. Lagged Inflation has a significant and negative effect on economic profit, with a one percent rise in inflation associated with a 0.7 percent loss in real after-tax economic profit. As expected, cyclical improvements in the manufacturing capacity utilization rate are associated with higher economic profit. This supports the hypothesis that inflation lowers the after-tax profit measure that is discounted by the market in determining real stock prices.

For measured profit, the hypothesis is that tax effects inflate profit, artificially raising the tax burden. The comparable equation for the logarithm of real after-tax corporate profit (Ip) over the same period is:

5) $d($ lp) $=0.011+0.022 d(\pi)+1.382 d($ Icu $)$

(2.03) (6.17) (4.41)

Adjusted $\mathrm{R}^{2}=0.31 \quad$ S.E. $=0.070 \quad$ D.W. $=2.30$

A one-percentage point rise in inflation raises real after-tax measured profit by 2.2 percent. This also supports the tax effect hypothesis and the popular view that inflation boosts profit, despite the fact that the true effect is negative, as seen in equation 4. A rise in the capacity utilization rate is associated with a 1.38 percent rise in real after-tax measured corporate profit.

Another indicator of the role of inflation in affecting returns to capital via depreciation accounting rules is to look at the performance of the longer-term structures net stock of capital relative to the net stock of equipment and software at the beginning of the Great Inflation. 
Figure 5

Structures Capital Formation Slowed from 1965 to 1978 due to the Great Inflation

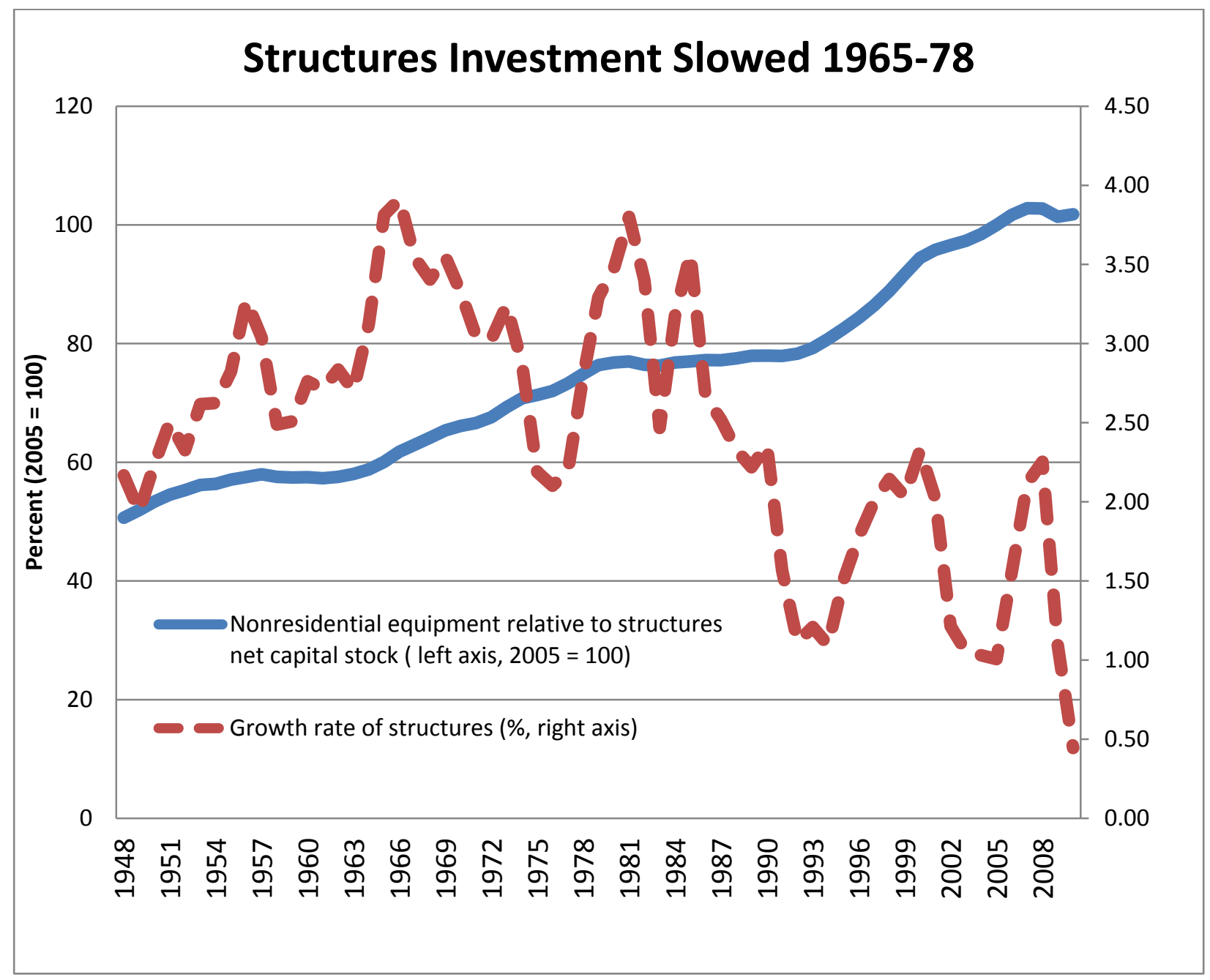

Source: Bureau of Economic Analysis, U.S. of Department of Commerce

\section{Conclusion}

Inflation is a monetary phenomenon. A more rapid and sustained pace of growth in the stock of money is the principal source of a higher and sustained pace of general price increase or inflation. There are non-monetary sources of temporary inflation such as large relative price changes associated with supply shocks, empirically especially due to energy price shocks that can boost inflation temporarily. Expected inflation tends to raise nominal interest rates and reduce bond prices. When money is neutral, real interest rates and real rates of return on equity are unaffected by inflation. However, even in this case, supply shocks that reduce productivity and real income, including the productivity of real capital, reduce real rates of return on equity and bonds. Monetary growth and inflation are not neutral, even when 
expected. For a variety of reasons reviewed here, inflation tends to raise investors' required real rate of return on equity and to lower real capital income for tax-related reasons. As a result, there is a strong negative correlation between inflation and real and nominal stock prices. The latter effect can be compounded by an expected policy reaction to slow future inflation and dampen inflation expectations, but with the potential to temporarily reduce economic activity. Contrary to opinion, equities are not a good hedge against inflation. Some alternative investments may be better, such as owner-occupied housing, land or other noncorporate investments that are not as affected by tax rules on depreciation and inventory accounting. Corporate investments in sectors or firms with smaller shares of capital assets, especially long-term assets, are closer to being satisfactory inflation hedges.

Tax effects discriminate most against equities of firms that are relatively more dependent on long-duration assets than those relatively more dependent on short-lived equipment and structures, as well as on firms that supply such long-lived assets. Temporary inflation associated with supply shocks also has differential effects across industries, affecting relative prices, output and employment more heavily in industries that use the affected resources or goods and services and therefore their equity and bond values. Not surprisingly, oil price shocks have larger effects on industries using energy more intensively, their customers and suppliers, and therefore they affect their equity and bond values more.

Indexing the tax system tends to weaken many of the effects highlighted here. Indexing the cost basis for depreciation and inventory accounting would offset many of these effects. Increasing information on economic policy could provide more stability and accuracy to expectations and alleviate some of the redistributive effects that can accompany shifts in the inflation rate. Policy reactions go well beyond the scope of this investigation, however. 


\section{References}

Bakshi, Gurdip S. and Zhiwu Chen (1996). "Inflation, Asset Prices, and the Term Structure of Interest Rates in Monetary Economies," Review of Financial Studies 9, 241-76.

Barro, Robert J. (1996). "Inflation and Growth," Federal Reserve Bank of St. Louis Review, 48 (3), May/June, 153-69.

Bernanke, Ben S. (2004). "The Great Moderation," speech to Eastern Economics Association, Feb. 20. http://www.federalreserve.gov/boarddocs/speeches/2004/20040220/default.htm.

Blanchard, Olivier, and John Simon (2001). "The Long and Large Decline in U.S. Output Volatility," Brookings Papers on Economic Activity, 1, 135-64.

Bordo Michael D. and David C. Wheelock (2007). "Stock Market Booms and Monetary Policy in the Twentieth Century," Federal Reserve Bank of St. Louis Review 89 (2), March, 91-122.

Brandt, M.W. and K.Q. Wang (2003). "Time Varying Risk Aversion and Unexpected Inflation," Journal of Monetary Economics 50, 1457-98.

Crone, Theodore, N. Neil K. Khettry, Loretta Mester and Jason Novak (2011), "Core Measures of Inflation as Predictors of Total Inflation," Federal Reserve Bank of Philadelphia Working Paper No. 11-24.

Fama, Eugene F. (1981). "Stock Returns, Real Activity, Inflation, and Money," American Economic Review 71, 545-65.

Fama, Eugene F and Kenneth R. French (1989). "Stock Returns, Expected Returns, and Real Activity," Journal of Financial Economics 45, 1089-1108.

Feldstein, Martin (1981). "Inflation and the Stock Market," American Economic Review, September, 839-47.

Friedman, Milton (1956). "The Quantity Theory of Money--A Restatement," in Milton Friedman, ed., Studies in the Quantity Theory of Money, Chicago: University of Chicago Press, pp. 3-21.

Hess, Patrick J. and Bong-Soo Lee (1999). "Stock Returns and Inflation with Supply and Demand Disturbances," Review of Financial Studies 12 (5), 1203-1218.

Kiley, Michael T. (2008). "Estimating the Common Trend Rate of Inflation for Consumer Prices and Consumer Prices excluding Food and Energy Prices," Board of Governors of the Federal Reserve System Finance and Economic Discussion Series 2008-38, August. 
Kim, Chang-Jin, and Charles Nelson (1999). "Has the U.S. Economy Become More Stable? A Bayesian Approach Based on a Markov-Switching Model of the Business Cycle," Review of Economics and Statistics, 81, 608-16.

Kim, Chang-Jin, Charles Nelson, and Jeremy Piger (2004). "The Less Volatile U.S. Economy: A Bayesian Investigation of Timing, Breadth, and Potential Explanations," Journal of Business and Economic Statistics 22 (1), January, 80-93. Mankiw, N. G., R. Reis and J. Wolfers (2003). "Disagreements about Inflation Expectations," NBER Macroeconomics Annual, MIT Press, 209 270.

McConnell, Margaret, and Gabriel Perez-Quiros (2000). "Output Fluctuations in the United States: What Has Changed since the Early 1980s?" American Economic Review 90, 1464-76.

Piazzesi, Monika and Martin Schneider (2008). "inflation and the Price of Real Assets," Stanford University Working Paper, April.

Rasche, Robert H. and John A. Tatom (1981). "Energy Price Shocks, Aggregate Supply and Monetary Policy: The Theory and International Evidence," in K. Brunner and A. H. Meltzer, eds., Supply Shocks, Incentives and National Wealth, Carnegie-Rochester Conference Series on Public Policy 14, 9-93.

Rasche, Robert H. and John A. Tatom (1977). "The Effect of the New Energy Regime on Economic Capacity, Production, and Prices" Federal Reserve Bank of St. Louis Review, May.

Rich, Robert W. and Charles Steindel (2007). "A Comparison of Measures of Core Inflation," Federal Reserve Bank of New York Economic Policy Review 13 (3), December, 19-38. ,

Stulz, Rene M. (1986). "Asset Pricing and Expected Inflation," Journal of Finance 41 (1), 209223.

Tatom, John A. (2002). "Stock Prices, Inflation and Monetary Policy," Business Economics, October, 7-19.

Tatom, John A. and James E. Turley (1978). "Inflation and Taxes: Disincentives for Capital Formation" Federal Reserve Bank of St. Louis Review, January. Reprinted in Federal Reserve Readings on Inflation, Federal Reserve Bank of New York, February 1979, 167-73. 